\title{
Production, formulation and antagonistic activity of the biocontrol like-yeast Aureobasidium pullulans against Penicillium expansum
}

\author{
R. Mounir · A. Durieux $\cdot$ E. Bodo $\cdot$ C. Allard · \\ J.-P. Simon · E.-H. Achbani · S. El-Jaafari · \\ A. Douira $\cdot$ M.-H. Jijakli
}

Received: 5 October 2006/ Revised: 23 November 2006/ Accepted: 27 November 2006 /

Published online: 10 January 2007

(C) Springer Science+Business Media B.V. 2007

\begin{abstract}
Aureobasidium pullulans (de Bary) Arnaud (Ach 1-1) was grown in a glucose fed-batch fermentor to 106 g dry wt $\mathrm{l}^{-1}$ in $48 \mathrm{~h}$. The cells were dried in a fluidized bed dryer with a final viability of $62 \%$. After 7 months at $4^{\circ} \mathrm{C}$, the viability was $28 \%$ of the initial value $\left(=2.3 \times 10^{10}\right.$ c.f.u. $\mathrm{g}^{-1}$ dry matter). A protection level of $89 \%$ was achieved with the biomass preparation at $1 \times 10^{8}$ c.f.u. $\mathrm{ml}^{-1}$
\end{abstract}

\section{R. Mounir · E.-H. Achbani}

Laboratoire de Phytobactériologie, Institut National de la Recherche Agronomique, BP 579, Meknès VN, Morocco

R. Mounir · A. Douira

Laboratoire de Botanique et de Protection des cultures, Université Ibn Tofail Faculté des Sciences, BP 133, 14000 Kenitra, Morocco
A. Durieux $(\bowtie) \cdot$ E. Bodo · C. Allard .
J.-P. Simon
Unité de Biotechnologie, Université Libre de
Bruxelles, Institut Meurice, Avenue Emile Gryzon 1, 1070 Bruxelles, Belgium
e-mail: a.durieux@meurice.ubt.be
S. El-Jaafari
Laboratoire de Biotechnologie et Amélioration des Plantes (UMI-BAP), Université de Moulay Ismail, BP 4010, Meknès, Morocco

\section{M.-H. Jijakli}

Unité de Phytopathologie, Faculté Universitaire des Sciences Agronomiques, Passage des Déportés 2, 5030 Gembloux, Belgium after 28 and 7 days for apples stored respectively at 5 and $25^{\circ} \mathrm{C}$ against Penicillium expansum. Our process is suitable to produce large quantities of the strain Ach 1-1 as biological control agent for apple preservation.

Keywords Antagonistic activity · Aureobasidium pullulans $\cdot$ Biofungicide formulation · Biological control agent - Biomass production - Post-harvest treatment

\section{Introduction}

Morocco is the second largest producer of apples in Africa after South Africa and contributes for $30 \%$ of African apples production. In this country, post-harvest pathogens cause substantial losses $(60 \%)$ in the apple production. Botrytis cinerea and Penicillium expansum are two important wound fungal pathogens causing decay of apples during storage. Currently, synthetic fungicides treatments are used to control these infections but the development of resistant strains of the pathogens to many fungicides and the growing concern for human safety and environmental protection (Caffarelli et al. 1999), have resulted in attempts to develop biological agents as alternative methods to control post-harvest diseases (Jijakli and Lepoivre 2004). 
Several microorganisms, particularly yeasts occurring naturally on the surface of fruits or vegetables, have been identified for the control of post-harvest diseases. Some are capable of effectively reducing the incidence of post-harvest fungal pathogens on different fruits, both in small-scale experiments and at industrial scale (Jijakli et al. 1999; Lima et al. 2003). The antagonistic activity of biocontrol agents against fungal pathogens results from the combination of different mechanisms including antibiosis, parasitism by production of lytic enzymes, induction of fruit resistance mechanisms and competition for limiting nutrients and space. The evaluation of these yeasts in a suitable formulation is essential to predict their potential use as biocontrol agent (Abadias et al. 2003). Yeast-based biofungicides are already commercially available in the USA, Israel (Aspire, based on Candida oleophila, strain I-182) (Droby et al. 1998) and South Africa (Yield Plus, Cryptococcus albidus) for the control of post-harvest rots of apple and/or citrus fruits.

The yeast-like fungus Aureobasidium pullulans (de Bary) Arnaud is a wide-spread saprophyte in the phyllosphere that has been considered as an effective biocontrol agent against post-harvest diseases (Lima et al. 1997; Schena et al. 1999; Ippolito et al. 2000; Castoria et al. 2001). Recently, A. pullulans strain Ach 1-1 was isolated from the surface of apple fruit in Morocco and previously selected for its high antagonistic activity against Penicillium expansum and Botrytis cinerea (Achbani et al. 2005). This study is the first investigation of biomass production; formulation and evaluation of the formulated yeast for its antagonistic activity at pilot scale.

\section{Materials and methods}

Strain and stock medium

Aureobasibium pullulans Ach1-1 (INRA, Meknès, Morocco) and Penicillium expansum strain 880 (INRA, Meknès, Morocco), isolated from decayed apples as the most aggressive strain, were both grown on potato dextrose agar (PDA) medium.
Culture in shake-flasks

Stock cultures $1 \mathrm{ml}$, were inoculated into $100 \mathrm{ml}$ liquid YEPD medium (containing per litre: $10 \mathrm{~g}$ yeast extract, $10 \mathrm{~g}$ soy peptone and $20 \mathrm{~g}$ glucose).

Culture in fermentor-batch mode

Propagation was carried out at $28^{\circ} \mathrm{C}$ in a 21 Biostat B bioreactor (B. Braun Biotech, Melsungen, Germany) for batch processes. The medium contained per litre: $5 \mathrm{ml}$ of mineral salts concentrated solution $\left(0.32 \mathrm{~g} \mathrm{l}^{-1} \mathrm{MnCl}_{2} \cdot 4 \mathrm{H}_{2} \mathrm{O}, 0.49 \mathrm{~g} \mathrm{l}^{-1}\right.$ $\mathrm{CuSO}_{4} \cdot 5 \mathrm{H}_{2} \mathrm{O}, 5.75 \mathrm{~g} \mathrm{l}^{-1} \mathrm{ZnSO}_{4} \cdot 7 \mathrm{H}_{2} \mathrm{O}, 0.48 \mathrm{~g} \mathrm{l}^{-1}$ $\mathrm{CoCl}_{2} \cdot 6 \mathrm{H}_{2} \mathrm{O}, 0.49 \mathrm{~g} \mathrm{l}^{-1} \mathrm{Na}_{2} \mathrm{MoO}_{4} \cdot 2 \mathrm{H}_{2} \mathrm{O}, 15 \mathrm{~g} \mathrm{l}^{-1}$ EDTA, $2.94 \mathrm{~g} \mathrm{l}^{-1} \quad \mathrm{CaCl}_{2} \cdot 2 \mathrm{H}_{2} \mathrm{O}$ and $2.78 \mathrm{~g} \mathrm{l}^{-1}$ $\mathrm{FeSO}_{4} \cdot 7 \mathrm{H}_{2} \mathrm{O}$ ), $30 \mathrm{~g}$ yeast extract, $30 \mathrm{~g}$ soy peptone, $0.37 \mathrm{~g} \mathrm{Na}_{2} \mathrm{SO}_{4}, 4.5 \mathrm{~g} \mathrm{~K}_{2} \mathrm{SO}_{4}, 6 \mathrm{~g} \mathrm{KH}_{2} \mathrm{PO}_{4}$, $3 \mathrm{~g} \mathrm{MgSO}_{4} \cdot 7 \mathrm{H}_{2} \mathrm{O}, 110 \mathrm{~g}$ glucose and $5 \mathrm{ml}$ vitamins concentrated solution $\left(1 \mathrm{~g} \mathrm{l}^{-1}\right.$ thiamine $\mathrm{HCl}$, $1 \mathrm{~g} \mathrm{l}^{-1}$ pyridoxine $\mathrm{HCl}, 1 \mathrm{~g} \mathrm{l}^{-1}$ nicotinic acid, $1 \mathrm{~g} \mathrm{l}^{-1}$ D-biotin, $1 \mathrm{~g} \mathrm{l}^{-1}$ Ca-pantothenate, $0.2 \mathrm{~g} \mathrm{l}^{-1}$ $p$-aminobenzoic acid, $5 \mathrm{~g} \mathrm{l}^{-1}$ inositol). Glucose and vitamins were sterilised separately. The medium was continuously aerated with $1.5 \mathrm{vvm}$, the stirring speed was maintained at $600 \mathrm{rpm}$. The $\mathrm{pH}$ of the medium was regulated by addition of $2 \mathrm{~m} \mathrm{NaOH}$ or $10 \%(\mathrm{v} / \mathrm{v}) \mathrm{H}_{3} \mathrm{PO}_{4}$. The bioreactor was inoculated with $100 \mathrm{ml}$ shake culture. Growth was estimated by measuring $\mathrm{OD}_{660}$ and by dry cell weight determination (DCW). Glucose and ethanol were measured by HPLC.

Culture in fermentor-fed-batch mode

In fed-batch experiment, the base medium was the same than for the batch experiments. The initial volume was adjusted to 51 in a 101 bioreactor (Biostat ED B. Braun Biotech, Melsungen, Germany). Glucose and concentrated vitamins solution were added before inoculation at, respectively, $5 \mathrm{~g} \mathrm{l}^{-1}$ and $5 \mathrm{ml} \mathrm{l}^{-1}$. Fed-batch solution consisted of $50 \%(\mathrm{w} / \mathrm{w})$ glucose.

\section{Drying}

Biomass production was achieved by culturing the fungus in a 101 fermentor in fed-batch mode. The 
biomass was harvested by centrifugation for $30 \mathrm{~min}$ at $12000 \mathrm{~g}$. Maize starch $(29 \% \mathrm{w} / \mathrm{w})$ was used as loading agent to allow the extrusion of the biomass by increasing the initial dry matter rate. The paste was extruded immediately into the dryer through holes of $1 \mathrm{~mm}$ diam. Yeast was dried to a final moisture content of $7.5 \%(w / w)$ in a fluidized bed dryer (Niro-Aeromatic, Denmark). The air-flow was adjusted at $150 \mathrm{~m}^{3} \mathrm{~h}^{-1}$ and the temperature was regulated to maintain $30^{\circ} \mathrm{C}$ inside the bed.

Viability of $A$. pullulans during storage

After drying, the samples were stored at $4^{\circ} \mathrm{C}$ and at various times there after the number of viable cells was determined by plating on YEPD medium. For this purpose, three replicates of each granular sample were dissolved by stirring in an isotonic solution $(0.9 \%(\mathrm{w} / \mathrm{w}) \mathrm{NaCl}$ and $0.05 \%$ (w/w) of soy peptone) for $2 \mathrm{~h}$.

Antagonistic activity of dried $A$. pullulans cells against $P$. expansum on apples

The efficacy of dried A. pullulans strain Ach 1-1 cells stored for 7 months at $4^{\circ} \mathrm{C}$ was evaluated for control of P. expansum on Golden Delicious fruits.

A conidial suspension of $P$. expansum at concentration of $1 \times 10^{5}$ c.f.u. $\mathrm{ml}^{-1}$ was prepared with 10-day-old cultures grown on PDA to be used in disease control experiments.

Apples were wounded at four equidistant points. Each wound was characterised by a diameter of $2 \mathrm{~mm}$ and a depth of $4 \mathrm{~mm}$ and a inter-wounds distance of $20 \mathrm{~mm}$. Fruits were dipped in $A$. pullulans suspensions at concentration of $1 \times 10^{6}, 1 \times 10^{7}$ or $1 \times 10^{8}$ c.f.u. $\mathrm{ml}^{-1}$ for $2 \mathrm{~min}$.

Twenty-four hours after $A$. pullulans application, $2 \mathrm{ml}$ conidial suspension of $P$. expansum were pulverized on each wounded apple. Fruits were stored at 25 and $5^{\circ} \mathrm{C}$ under relative humidity of $94-98 \%$ in closed plastic trays. Each treatment was applied to three replicates of 20 fruits. The lesion severity (lesion diameter in $\mathrm{mm}$ ) caused by $P$. expansum was measured after several days. The protective levels $(Y \%)$ were calculated with respect to the following formula: $D_{\mathrm{T}}-D_{\mathrm{X}} /$
$D_{\mathrm{T}} \times 100=Y \%$, with $D_{\mathrm{T}}=$ diameter lesion of control and $D_{\mathrm{X}}=$ diameter lesion of treatment.

\section{Results and discussion}

Effect of $\mathrm{pH}$ on morphology and mass production in 2-1 bioreactor in batch mode

The $\mathrm{pH}$ of the medium is a critical factor in biomass production by $A$. pullulans because it affects its morphology (Hyung-Pil et al. 2004). In batch experiments, during fermentation in a bioreactor of 21 , the maximum mass production of strain Ach1-1 was reached at $\mathrm{pH} 5.0$ with $\mathrm{DCW}=39.7 \mathrm{~g} \mathrm{l}^{-1}$ at the end of the fermentation and a yield coefficient $\left(\mathrm{Y}_{\mathrm{X} / \mathrm{S}}\right)$ of 0.36 after $48 \mathrm{~h}$. At $\mathrm{pH} 4.0$ and at $\mathrm{pH} 6.5$ the final biomass concentrations (DCW) respectively were 26.2 and $22 \mathrm{~g} \mathrm{l}^{-1}$ after $48 \mathrm{~h}$ (Fig. 1).

At $\mathrm{pH}$ 4.0, A. pullulans produced both mycelia and yeast-like single cells (Bae et al. 2000). However, the mycelial form changed to the yeast-like single cell form at $\mathrm{pH} 5.0$ which is more suitable use as a biocontrol agent due to its improved dispersability.

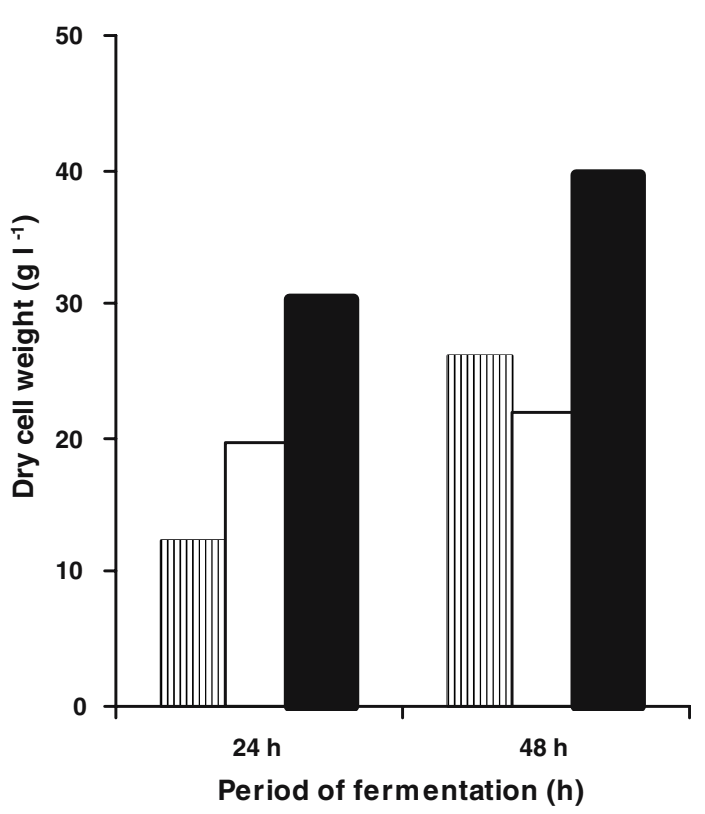

Fig. 1 Effect of $\mathrm{pH}$ on dry weight cell in bioreactor of 21 . $\mathrm{pH}$ controlled at $4(\mathbf{m}), 5(\mathbf{m})$ and $6.5(\square)$ throughout the batch fermentation period 
Optimization of biomass production

by using fed-batch mode

High cell density fermentation was achieved using fed-batch technology with $\mathrm{pH}$ controlled at 5.0. After $48 \mathrm{~h}$, the biomass was $106 \mathrm{~g} \mathrm{l}^{-1}$. The glucose profile was adjusted to avoid any limitation of $\mathrm{O}_{2}$ as shown in Fig. 2 favouring the respiratory metabolism. The use of fed-batch culture was more favourable for biomass production by reduction of by-products such as ethanol. Indeed, the maximum for ethanol production in the batch mode reached $28 \mathrm{~g} \mathrm{l}^{-1}$ and was reduced down to $0.1 \mathrm{~g} \mathrm{l}^{-1}$ in the fed-batch mode.

Viability of the dried yeast $A$. pullulans

The drying process was accomplished using fluidised bed drying technology. The changes in viability during the drying process are presented in Fig. 3. The final product showed a high rate of viability $(62 \%)$ corresponding to a residual moisture of $7.5 \%(\mathrm{w} / \mathrm{w})$. Such a percent viability is totally acceptable for industrial scale production of a biocontrol agent for fruit preservation (Aba-

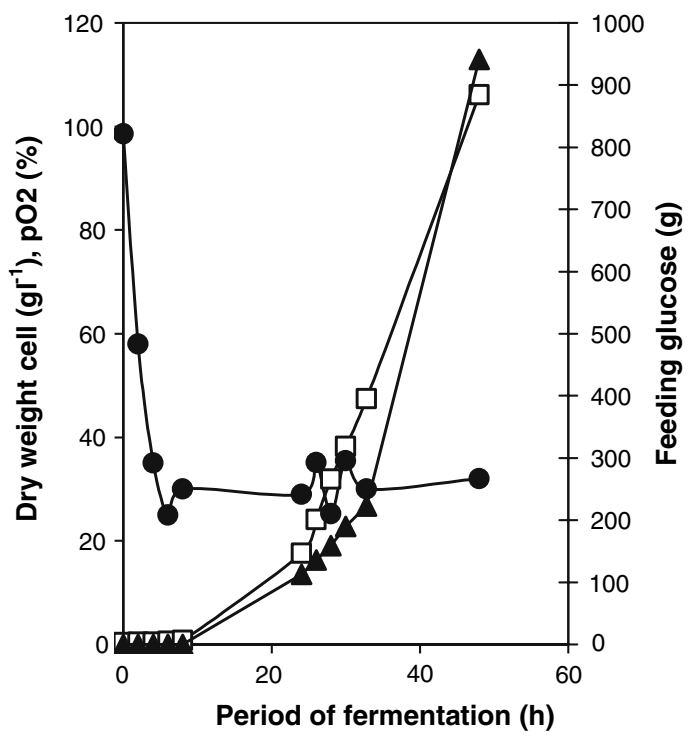

Fig. 2 Feeding of the glucose $(\mathrm{g})(\mathbf{\Delta})$, evolution of $\mathrm{OD}_{660}$ $(\square)$ and $\mathrm{pO}_{2} \%(\bullet)$ throughout fed-batch fermentation. The solution was added following an exponential profile adjusted by an Ultrograd (Pharmacia) via a peristaltic pump

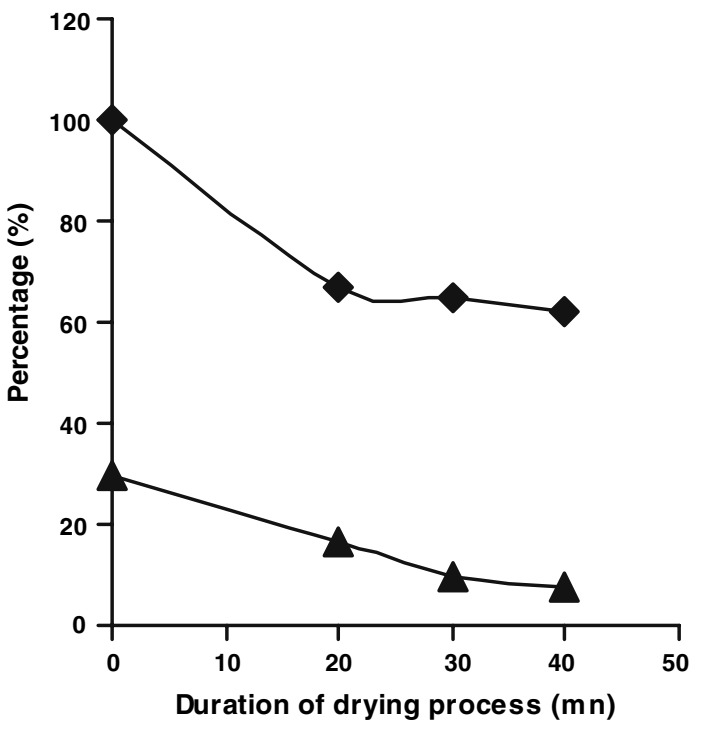

Fig. 3 Viability (\%) (४), Residual moisture (\%w/w) (A) of $A$. pullulans Ach 1-1 during the drying process

dias et al. 2003). After 7 months of storage at $4^{\circ} \mathrm{C}$, $28 \%$ of initial viability corresponding to $2.3 \times 10^{10}$ c.f.u. $\mathrm{g}^{-1}$ dry matter was observed. This drop in viability occurred in the first 30 days of storage at $4^{\circ} \mathrm{C}$. After that period, the viability remained constant.

Antagonistic activity of $A$. pullulans formulation against $P$. expansum on apples

The dried formulation of $A$. pullulans was evaluated for its antagonistic activity against the $P$. expansum at a pilot scale for two storage temperatures, 5 and $25^{\circ} \mathrm{C}$. In each test, the inoculation of the apple was carried out with the same concentration of pathogen. The severity (lesion diameter) of decay due to the pathogen infection was submitted to an analysis of variance (ANO$\mathrm{VA}$ ) using the general linear model procedure of Statistical Analysis System (SAS Institute, Cary, NC, USA). Statistical significance was judged at the $P<0.05$ level. When the analysis revealed statistically significant differences, Duncan's Multiple-Range Test was used to test mean separations among means values of each treatment.

Statistically, the lesion diameters caused by $P$. expansum in all treatments were significantly reduced for all biological treatments with $A$. pullu- 
lans at different concentrations $\left(1 \times 10^{6}, 1 \times 10^{7}\right.$ and $1 \times 10^{8}$ c.f.u. $\mathrm{ml}^{-1}$ ) compared to the untreated control for both temperature of storage, 5 and $25^{\circ} \mathrm{C}$.

The concentrations of antagonist had significant effects on biocontrol effectiveness; the best control of blue mold caused by $P$. expansum inoculated at a concentration of $1 \times 10^{5}$ c.f.u. $\mathrm{ml}^{-1}$ was achieved by application of $A$. pullulans at a concentration of $1 \times 10^{8}$ c.f.u. $\mathrm{ml}^{-1}$.

For apples stored at $25^{\circ} \mathrm{C}$, the different concentrations of dried formulation of strain Ach1-1 used reduced the severity of the disease (Fig. 4a). The use of dried formulation of strain Ach1-1 at $1 \times 10^{8}$ c.f.u. $\mathrm{ml}^{-1}$ showed the highest protective level $(89 \%)$ after 7 days of storage (Fig. 4b) whereas both lower concentrations $\left(1 \times 10^{6}\right.$ and $1 \times 10^{7}$ c.f.u. $\mathrm{ml}^{-1}$ ) offered a protective level ranged between 46 and $71 \%$. Our results are in accordance with those of El-Ghaout et al. (2000) who observed a more effective control of postharvest decay with antagonistic yeasts applied at $1 \times 10^{8}$ c.f.u.ml ${ }^{-1}$ and often no control of decay when biocontrol agents were applied at $1 \times 10^{5}$ c.f.u. $\mathrm{ml}^{-1}$.

Similar results were also observed for apples stored at $5^{\circ} \mathrm{C}$. The use of a dried formulation of strain Ach1-1 at $1 \times 10^{8}$ c.f.u. $\mathrm{ml}^{-1}$ showed also the highest protective level of $89 \%$ after 28 days of storage (Fig. 4b) whereas both lower concentrations $\left(1 \times 10^{6}\right.$ and $1 \times 10^{7}$ c.f.u. $\left.\mathrm{ml}^{-1}\right)$ offered a protective level between 48 and $81 \%$.

For apples stored at $5^{\circ} \mathrm{C}$, the first symptoms of disease appeared after 13 days. The level of protection obtained with the dried formulation of strain Ach1-1 $\left(1 \times 10^{8}\right.$ c.f.u. $\left.\mathrm{ml}^{-1}\right)$ at day 20 was of $98 \%$ and decreased to $89 \%$ after 28 days.
Fig. 4 Biocontrol activity of dried A. pullulans (strain Ach 1-1) against P. expansum. A. pullulans suspension applied at a concentration of $1 \times 10^{6}$ c.f.u. $\mathrm{ml}^{-1}(\mathrm{~m}), 1 \times 10^{7}$ c.f.u. $\mathrm{ml}^{-1}$ (娄) and $1 \times 10^{8}$ c.f.u. $\mathrm{ml}^{-1}(\mathbf{\square})$ with control $(\square)$. The protective level (a) and severity (b) of decay were determined after 5 and 7 days of storage at $25^{\circ} \mathrm{C}$ and after 20 and 28 days of storage at $5^{\circ} \mathrm{C}$
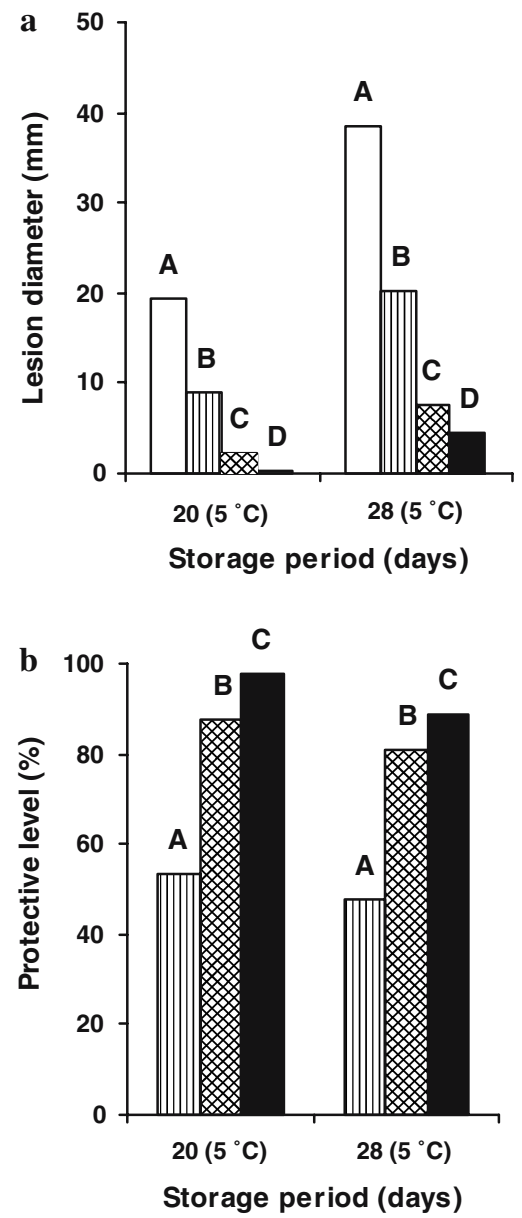
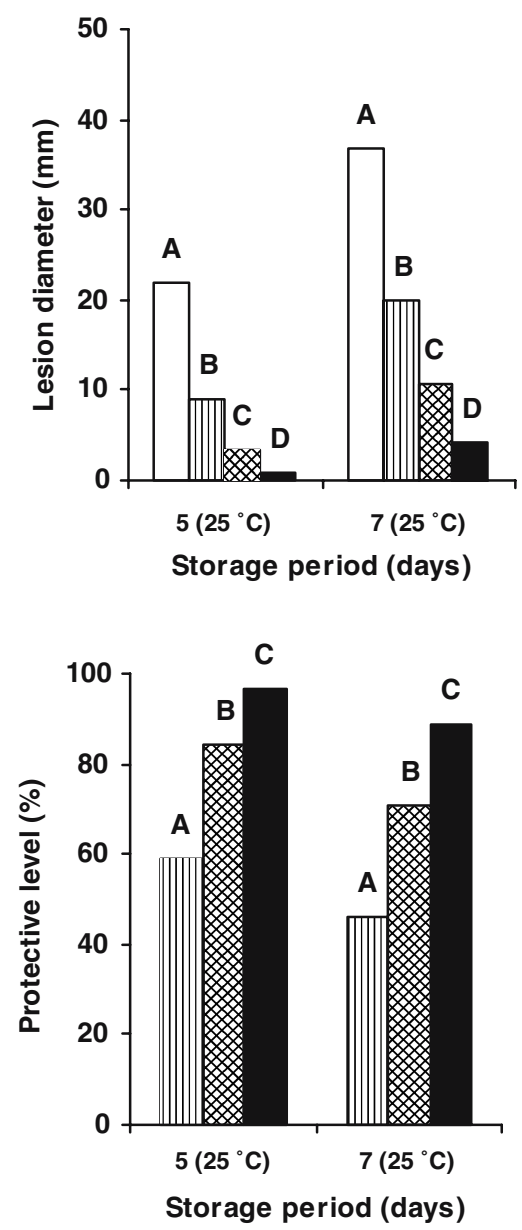
The efficiency of the biological control agent in inhibiting the development of the pathogen for long periods of storage was greater at $5^{\circ} \mathrm{C}$ than at $25^{\circ} \mathrm{C}$. It is thus important to keep apple fruit at a low temperature to achieve a high level of protection. Similar results were observed by $\mathrm{He}$ et al. 2003 who studied the effect of different storage temperatures $\left(10,15\right.$ and $\left.20^{\circ} \mathrm{C}\right)$ on apple decay after the inoculation of the antagonist yeast, Cryptococcus laurentii, against Penicillium expansum and concluded that the antagonistic effects were inversely related to the storage temperature.

The results obtained for fruit stored at high temperature $\left(25^{\circ} \mathrm{C}\right)$ after 5 and 7 days were similar to those obtained at the lower temperature $\left(5^{\circ} \mathrm{C}\right)$, respectively after 20 and 28 days. The efficacy test at $25^{\circ} \mathrm{C}$ can then be used as a quick method to predict the efficacy at $5^{\circ} \mathrm{C}$.

\section{Conclusions}

This study demonstrates that biomass production in a fermentor and formulation in dried cells in fluid bed of $A$. pullulans Ach 1-1 does not affect its antagonistic activity against blue mould on apples.

The strain Ach 1-1 was able to reduce postharvest blue mould development on apple. The antagonist efficacy at 25 and $5^{\circ} \mathrm{C}$ indicates excellent adaptation of this strain to cold storage temperatures, what is an important feature for post-harvest biocontrol agents.

Although these experiments showed that $A$. pullulans Ach 1-1 was effective in controlling blue mould under laboratory conditions and that its efficacy could be improved by a concentration of $1 \times 10^{8}$ c.f.u. $\mathrm{ml}^{-1}$, large-scale evaluation is necessary to demonstrate the efficacy of this treatment to the apple industry.

Biological control in the post-harvest environment has significant advantages over that under field conditions because the two most important factors affecting biocontrol, temperature and relative humidity are constant and under strict control.

Acknowledgements Thanks to C.U.D. Belgium for funding this study that constitutes a part of the "PIC" project "Biological control of apple postharvest diseases". Thanks to A-M Plaisant, A Benbouazza, G Foroni, L Garre and J-P Defroyennes for their excellent technical support.

\section{References}

Abadias M, Teixidó N, Usall J, Viňas I (2003) Optimization of growth conditions of the postharvest biocontrol agent Candida sake CPA-1 in a lab-scale fermenter. J Appl Microbiol 95:301-309

Achbani EH, Mounir R, El Jaafari S, Douira A, Benbouazza A, Jijakli H (2005) Selection of antagonists against Penicillium expansum and Botrytis cinerea, two post harvest apple parasites. 57th International Symposium on Crop Protection. Commun Agric Biol Sci Ghent University 70(3):143-149

Bae JT, Sinha J, Park JP, Dong CH, Yun JW (2000) Optimization of submerged culture conditions for exo-biopolymer production by Paecilomyces japonica. J Microbiol Biotechnol 10:482-487

Caffarelli V, Rapagnani MR, Letardi A, Triolo L, Santaroni P, Lancia B (1999) Pesticide residues in horticultural product and carcinogenic risk for consumers. In: Del Re AAM, Brown CD, Capri E, Errera G, Evans SP, Trevisan M (eds) Human environmental exposure to xenobiotics. La Goliardica Pavese, Pavia, pp 665-669

Castoria R, De Curtis F, Lima G, Caputo L, Pacifico S, De Cicco V (2001) Aureobasidium pullulans (LS-30) an antagonist of post-harvest pathogens of fruits: study on its modes of action. Postharvest Biol Technol 22: $7-17$

Droby S, Cohen L, Daus A, Weiss B, Horev B, Chalutz E, Katz H, Keren-Tzun M, Shachnai A (1998) Commercial testing of Aspire: a yeast preparation for the biocontrol of postharvest decays citrus. Biol Control 12:97-101

El-Ghaout A, Smilanick J, Wisniewski M, Wilson CL (2000) Improved control of apple and citrus fruit decay with a combination of Candida saitoana and 2deoxy-D-glucose. Plant Dis 84:249-253

He D, Zheng X-D, Yin Y-M, Sun P, Zhang H-Y (2003) Yeast application for controlling apple post-harvest diseases associated with Penicillium expansum. Bot Bull Acad Sin 44:211-216

Hyung-Pil S, Chung CH, Kim SK, Gross RA, Kaplan DL, Lee JW (2004) Mass production of pullulan with optimized concentrations of carbon and nitrogen sources by Aureobasidium pullulans HP-2001 in a 100-1 bioreactor with the Inner pressure. J Microbiol Biotechnol 14(2):237-240

Ippolito A, El Ghaouth A, Wilson CL, Wisniewski M (2000) Control of post-harvest decay of apple fruit by Aureobasidium pullulans and induction of defense responses. Postharvest Biol Technol 19:265-272

Jijakli MH, Lepoivre P, Grevesse C (1999) Yeast species for biocontrol of apple post-harvest diseases: An encouraging case of study for practical use. In: 
Upadhyay RK, Mukerji KG (eds). Biotechnological approaches in biocontrol of plant pathogens. Kluwer Academic/Plenum Publishers, New York, pp 31-49

Jijakli MH, Lepoivre P (2004) State of the art and challenges of post-harvest diseases management in apples. In: Mukerji KG (ed) Disease management of fruits and vegetables, fruit and vegetable diseases, vol 1. Kluwer Academic Publisher, New York, pp 59-94

Lima G, Ippolito A, Nigro F, Salerno M (1997) Effectiveness of Aureobasidium pullulans and Candida oleophila against post-harvest strawberry rots. Postharvest Biol Technol 10:169-178

Lima G, De Curtis F, Castoria R, De Cicco V (2003) Integrated control of apple post-harvest pathogens and survival of biocontrol yeasts in semi-commercial conditions. Eur J Plant Pathol 109:341-349

Schena L, Ippolito A, Zahavi T, Cohen L, Nigro F, Droby S (1999) Genetic diversity and biocontrol activity of Aureobasidium pullulans isolates against post-harvest rots. Postharvest Biol Technol 17:189-199 